\title{
Evaluation of a cohabitation challenge model in immunization trials for channel catfish Ictalurus punctatus against Ichthyophthirius multifiliis
}

\author{
De-Hai Xu* , Phillip H. Klesius, Craig A. Shoemaker \\ Aquatic Animal Health Research Laboratory, Agricultural Research Service, United States Department of Agriculture, \\ 990 Wire Road, Auburn, Alabama 36832, USA
}

\begin{abstract}
Calcein marking and cohabitation challenges have not been investigated in fish parasite research. This study evaluated a cohabitation challenge method in immunization trials against Ichthyophthirius multifiliis (Ich) using calcein, a fluorescent dye, to mark channel catfish Ictalurus punctatus (Rafinesque). Fish were marked by calcein immersion at 0,500 , and $1500 \mathrm{mg} \mathrm{l}^{-1}$, and then challenged with 15000 theronts fish ${ }^{-1}$. No difference was noted in fish infection levels, mortality, and mean days to death (MDD) caused by Ich between unmarked and marked fish or between fish marked with high (1500 $\mathrm{mg} \mathrm{l}^{-1}$ ) and low (500 $\mathrm{mg} \mathrm{l}^{-1}$ ) concentrations of calcein. After ensuring that calcein marking had no effect on the susceptibility of fish to Ich theronts, 2 immunization trials were conducted to evaluate the cohabitation challenge model using calcein-marked catfish. Fish mortality, relative percent survival (RPS), and MDD were compared between cohabitation-challenged fish and fish challenged by non-cohabitation. No significant difference was observed in RPS for cohabitationchallenged fish and fish challenged by non-cohabitation. A cohabitation challenge can be used as an alternative challenge method in parasite studies, since it closely mimics natural exposure.
\end{abstract}

KEY WORDS: Calcein • Cohabitation challenge · Immune response · Infection level . Ichthyophthirius · Channel catfish

\section{INTRODUCTION}

Epizootics of ichthyophthiriasis or 'white spot' have been reported in various freshwater fishes worldwide and cause heavy losses in aquaculture (Paperna 1972, Buchmann et al. 1995, Traxler et al. 1998). This disease is caused by a ciliated protozoan, Ichthyophthirius multifiliis (Fouquet, 1876), commonly referred to as Ich. I. multifiliis has 3 developmental stages: a reproductive tomont, an infective theront, and a parasitic trophont (Hines \& Spira 1974, Nigrelli et al. 1976).

Control of ichthyophthiriasis by using chemicals approved for food fish is not effective after the Ich penetrates fish skin and gills (Tieman \& Goodwin 2001). Chemical treatments are also costly and cause public concerns about food and environmental safety. Immunization against the parasite is an alternative to chemical treatments, since fish immunized with Ich acquire protective immunity against re-infection by the parasite (Hines \& Spira 1974, Wahli \& Meier 1985, Houghton \& Matthews 1990, Clark et al. 1996, Dickerson \& Clark 1998, Sigh \& Buchmann 2001, Wang \& Dickerson 2002).

One common challenge method used in immunization studies for Ich is exposure of fish to known amounts of infective theronts for a certain length of time (Dickerson et al. 1981, Lin et al. 1996, Dalgaard et al. 2002, Xu et al. 2004). This method can easily manage the number of theronts used and exposure duration, thereby providing acceptable challenge results. Fish can also be challenged by contact with Ichinfected fish (Goven et al. 1980, Wolf \& Markiw 1982). An infected fish showing visible trophonts is placed with naïve fish as the theront source. Because there is a great variation in the number of trophonts on the infected fish and the number of infective theronts 
released into the water, the infection level is not easy to control for the challenged naïve fish. Another challenge method is to expose fish to a known number of tomonts (Areerat 1974). However, the variable number of theronts released from each tomont makes it difficult to manage the infection level on challenged fish when using tomonts as the infection source.

Cohabitation challenges have been used in studies for evaluating protective immunity of vaccinated fish against bacteria (Erdal \& Reitan 1992, Klesius et al. 2006) and viruses (Raynard et al. 2001). In a recent study, sham-vaccinated Nile tilapia marked with calcein were cohabited with vaccinated tilapia and then challenged to evaluate the efficacy of vaccination (Klesius et al. 2006). In their model, the vaccinated and control fish were cohabited throughout the entire evaluation period by using a non-invasive calcein marking technique.

Most studies that evaluated immune protection against Ich were conducted using immunized and nonimmunized fish challenged in separate tanks (Burkart et al. 1990, Lin et al. 1996, He et al. 1997, Dalgaard et al. 2002, Xu et al. 2004). Alternately, cohabitation is considered one of the best models for evaluating protective immunity, since immunized and non-immunized fish are held in the same rearing unit (Nordmo 1997, Klesius et al. 2006), thereby decreasing the chance for variation between experimental units, such as the number of infective pathogens, exposure time, temperature, water quality, volume of flowing water, and amount of feed provided. Immune and nonimmune fish can be differentiated in the same tank by marking. There are several techniques available for marking fish, including fin clips, percutaneous tags, visible implant tags, coded wire tags and a fluorescent chromophore, calcein (Klesius et al. 2006). Tilapia immersed in $500 \mathrm{mg} \mathrm{l}^{-1}$ calcein solution for $4 \mathrm{~h}$ bore detectable fluorescent marking for longer than $45 \mathrm{~d}$ without undue stress or mortality (Klesius et al. 2006). Calcein marking and cohabitation challenges have not been investigated for fish parasite research. In the present study, we evaluated a cohabitation challenge method against Ich in immunization trials using calcein-marked channel catfish.

\section{MATERIALS AND METHODS}

Fish and parasite. Channel catfish Ictalurus punctatus (Rafinesque) were reared at the USDA Aquatic Animal Health Research Laboratory, Auburn, Alabama, USA. These fish $(11.8 \pm 0.7 \mathrm{~cm}$ in length, $10.5 \pm$ $1.4 \mathrm{~g}$ in weight; mean $\pm \mathrm{SD}$ ) were acclimated in $57 \mathrm{l}$ aquaria supplied with flowing dechlorinated water at approximately $0.51 \mathrm{~min}^{-1}$ for $1 \mathrm{wk}$ prior to trials. Water temperature ranged from 22 to $24^{\circ} \mathrm{C}$ during the trial period, and aeration was supplied by air stones. A light:dark period of 12:12 $\mathrm{h}$ was maintained at the experimental facility.

Ichthyophthirius multifiliis was isolated from an infected channel catfish from a fish pond in Alabama and maintained by continuous serial passages through channel catfish as previously described (Xu \& Klesius 2003). To prepare infective theronts for challenge trials, catfish infected with maturing trophonts (5 to $6 \mathrm{~d}$ after infection) were rinsed in tank water, and the skin was gently scraped to dislodge the parasites. Isolated trophonts were placed in a tank with water and incubated at 22 to $24^{\circ} \mathrm{C}$. Theronts were enumerated in five $1 \mathrm{ml}$ samples of theront solution with the aid of a Sedgewick-Rafter counting cell (Graticules).

Immunized fish. Infective theronts were added to aquaria containing 30 channel catfish each at a rate of 15000 theronts fish ${ }^{-1}$ for $1 \mathrm{~h}$. Catfish not exposed to Ich theronts served as non-immune control fish. When fish showed visible trophonts 4 to $5 \mathrm{~d}$ post-infection, the aquaria with infected fish were treated with formalin at a concentration of $100 \mathrm{mg} \mathrm{l}^{-1}$ (equivalent to $37 \mathrm{mg} \mathrm{l}^{-1}$ formaldehyde) for $1 \mathrm{~h}$ to kill theronts and prevent reinfection. The fish were treated daily for $5 \mathrm{~d}$ until no white spots were seen on gills and skin of the fish. The fish were then kept in the aquaria for 3 wk to allow protective immunity to develop.

Calcein-marked fish in challenge trials. Calcein $\left(\mathrm{C}_{30} \mathrm{H}_{26} \mathrm{~N}_{2} \mathrm{O}_{13}\right.$, Sigma Chemical) was dissolved in water at a concentration of $500 \mathrm{mg} \mathrm{l}^{-1}$. A total of 80 and 120 non-immune catfish were calcein-marked $(\mathrm{CM})$ in challenge Trial I and Trial II, respectively. Forty catfish were immersed in $10 \mathrm{l}$ calcein solution in a $19 \mathrm{l}$ bucket for $4 \mathrm{~h}$ with aeration, rinsed 5 times with fresh rearing water, and transferred to an aquarium with flowthrough water for $24 \mathrm{~h}$ to remove any excess calcein. Eighty immune catfish (40 fish per bucket) were immersed in water without addition of calcein (nonmarked, NM) in each challenge trial. The fish were then distributed into aquaria for experiments.

Detection of calcein mark. To inspect calcein fluorescent marks on fish, fish surviving the challenge were anesthetized with $100 \mathrm{mg} \mathrm{l}^{-1}$ tricaine methanesulfonate (MS-222, Argent Chemical Laboratories). Dead or anesthetized fish were placed in $150 \times$ $25 \mathrm{~mm}$ Petri dishes (Corning) and viewed under a fluorescence inverted microscope (Olympus American). Calcified skeletal structures in fins of calcein-marked fish showed intense fluorescence. The fluorescent marks on fish were also detected in the dark in the fish facility using either a Model ML-49 portable UV light or a plug-in mineral lamp Model UVGL-58 (Ultra-violet Products) as described by Klesius et al. (2006). 
Effect of calcein marking on the susceptibility of Ich theronts. To determine the effect of CM on the susceptibility of channel catfish to Ich theronts, 40 fish were put in each of four $19 \mathrm{l}$ buckets containing $10 \mathrm{l}$ water and aeration. Calcein was added to 3 buckets to make marking solutions of 500 and $1500 \mathrm{mg} \mathrm{l}^{-1}$ (2 buckets), respectively. A bucket without calcein $\left(0 \mathrm{mg} \mathrm{l}^{-1)}\right.$ served as an NM control. Fish in each bucket were immersed in calcein solution for $4 \mathrm{~h}$, rinsed, and distributed between two $57 \mathrm{l}$ aquaria with 20 fish per aquarium. Fish marked with $1500 \mathrm{mg} \mathrm{l}^{-1}$ from 1 bucket were placed in $2 \mathrm{CM}$ aquaria to serve as non-challenged controls. Fish in the remaining 6 tanks were challenged with 15000 theronts fish ${ }^{-1}$ for $1 \mathrm{~h}$. When fish showed visible trophonts $5 \mathrm{~d}$ after the challenge, infection levels for 5 fish in each aquarium were determined as described by $\mathrm{Xu}$ et al. (2004). The number of trophonts on the fish skin and fins was counted, and the infection level was assessed by respectively assigning scores of $0,1,2$, and 3 to fish that showed no infection, $<50,50-100$, and $>100$ trophonts fish $^{-1}$. Cumulative mortality of fish in each aquarium was recorded daily for $21 \mathrm{~d}$ after theront challenge.

Parasite loads in skin and gills of fish using different challenge methods. Nine $57 \mathrm{l}$ aquaria were used to monitor and compare parasite loads in skin and gills of fish post-challenge using 2 infection methods. Three aquaria were used for cohabitation, each containing 15 immune catfish without calcein marking (NM-immune) and 15 non-immune control fish with calcein marking (CM-control). In addition, each of 6 aquaria was stocked with either $30 \mathrm{NM}$-immune fish or $30 \mathrm{CM}$-control (3 aquaria per treatment). Prior to theront challenge, water in all aquaria was lowered to $10 \mathrm{l}$. Theronts were added to each aquarium at 30000 theronts fish ${ }^{-1}$. Fish were exposed to theronts for $1 \mathrm{~h}$ and then flowing water was provided to each aquarium at approximately $0.51 \mathrm{~min}^{-1}$. Two fish were sampled from each group in each aquarium daily for $7 \mathrm{~d}$. For skin parasite load, 2 wet mount slides were prepared per fish by scraping mucus and skin from a $2 \times 4 \mathrm{~cm}^{2}$ area of lateral body surface (1 slide per fish side). The number of parasites in skin samples was determined by scanning the entire wet mount from left to right and from top to bottom. Parasite loads were expressed as the number of parasites per skin sample. One gill filament sample $(5 \times 5 \mathrm{~mm})$ was cut from the opercular cavity on both sides of each fish ( 2 samples per fish). Gill samples were observed under a microscope, and the numbers of trophonts per sample were counted by randomly viewing 2 areas of $19.6 \mathrm{~mm}^{2}$ at $40 \times$ magnification (optical 10× and objective $4 \times$ ). Trophont loads in fish gills were expressed as the number of parasites per viewing area.

Challenge trials. Two trials were conducted to evaluate a cohabitation challenge method using calcein- marked channel catfish. In Trial I, 10 NM-immune and $10 \mathrm{CM}$-control fish were placed together in 1 of four 571 aquaria for cohabitation infection. In addition, 4 aquaria were stocked with $20 \mathrm{NM}$-immune or $20 \mathrm{CM}$ control fish per aquarium (2 aquaria per treatment). Prior to Ich challenge, water flow was halted, and water volume was lowered to $10 \mathrm{l}$ in all aquaria. Theronts were added to each aquarium at a concentration of 15000 theronts $\mathrm{fish}^{-1}$. Trial II was a repeated experiment of Trial I, and 8 tanks were set up as in Trial I. Forty CM-control catfish that were not challenged with theronts (non-challenge) were placed in 2 additional aquaria (20 fish per aquarium) in Trial II. Theronts were added to water in each aquarium at a concentration of 30000 theronts fish ${ }^{-1}$ except in nonchallenge control aquaria. Fish were exposed to theronts for $1 \mathrm{~h}$, after which water flow in the aquaria was resumed at approximately $0.5 \mathrm{l} \mathrm{min}^{-1}$. Fish mortality was monitored following the challenge for $21 \mathrm{~d}$ in both trials. Dead and surviving fish were inspected for calcein marks as previously described. Relative percent survival (RPS), defined as (1 - \% mortality of vaccinated fish $/ \%$ control mortality) $\times 100$ (Nordmo 1997), was used to compare fish survival between the 2 challenge methods.

Statistical analysis. All data analysis was performed with SAS software (SAS Institute 1989). Effects of calcein on the susceptibility of fish to Ich theronts, fish mortality, and infection levels were analyzed with Duncan multiple range tests. Relative percent survivals between fish in the cohabitation and non-cohabitation challenge were compared using a $t$-test. Mean days to death (MDD) was calculated by the Lifetest procedure (Kaplan-Meier method) in SAS. Probabilities of 0.05 or less were considered statistically significant.

\section{RESULTS}

\section{Effect of calcein marking on the susceptibility of Ich theronts}

Fish developed visible trophonts on fins and skin 4 d post-exposure to Ich theronts. No difference was noted for trophont infection level between NM fish and $\mathrm{CM}$ fish or between $\mathrm{CM}$ fish marked with calcein at 500 or $1500 \mathrm{mg} \mathrm{l}^{-1}(\mathrm{p}>0.05$, Table 1$)$. The trophont infection scores were from 2.4 to 2.6 , representing infection levels in fish from 50-100 to >100 trophonts fish $^{-1}$. Calcein marking had no effect on fish mortality or MDD. Fish exposed to Ich theronts showed 100\% mortality with a similar MDD (approximately 9 d), regardless of whether fish were $\mathrm{NM}$ or $\mathrm{CM}$. All unchallenged fish (CM-control) survived when marked with calcein at $1500 \mathrm{mg} \mathrm{l}^{-1}$. 
Table 1. Ictalurus punctatus. Infection level, mortality, and mean days to death (MDD) of fish treated with different concentrations of calcein and challenged by exposure to 15000 Ichthyophthirius multifiliis theronts fish $^{-1}$ for $1 \mathrm{~h}$. Within a given column, means with different superscripts are statistically different $(\mathrm{p}<0.05)$; na: not available

\begin{tabular}{|c|c|c|c|c|}
\hline $\begin{array}{l}\text { Calcein } \\
\left(\mathrm{mg} \mathrm{l}^{-1}\right)\end{array}$ & $\begin{array}{l}\text { Challenge } \\
\text { stage of Ich }\end{array}$ & $\begin{array}{l}\text { Infection } \\
\text { level }\end{array}$ & $\begin{array}{l}\text { Mortality } \\
(\%)\end{array}$ & $\begin{array}{l}\mathrm{MDD} \\
\pm \mathrm{SE}\end{array}$ \\
\hline 0 & Theronts & $2.6 \pm 0.5^{\mathrm{a}}$ & $100^{\mathrm{a}}$ & $9.0 \pm 0.4^{\mathrm{a}}$ \\
\hline 500 & Theronts & $2.5 \pm 0.6^{\mathrm{a}}$ & $100^{\mathrm{a}}$ & $9.4 \pm 0.4^{\mathrm{a}}$ \\
\hline 1500 & Theronts & $2.4 \pm 0.6^{a}$ & $100^{\mathrm{a}}$ & $9.1 \pm 1.0^{\mathrm{a}}$ \\
\hline 1500 & None & $0^{\mathrm{b}}$ & $0^{\mathrm{b}}$ & na \\
\hline
\end{tabular}

\section{Parasite loads in skin and gills of fish using different challenge methods}

Parasite loads in skin and gills of fish using different challenge methods are presented in Figs. 1 \& 2. The numbers of trophonts in the skin of control (nonimmune) fish in cohabited groups were lower than noncohabited control fish (Fig. 1). The parasite loads in the skin of cohabited fish or non-cohabited controls increased dramatically at Day 6 post-challenge. Most trophonts at Day 6 post-challenge were $1 \mathrm{~d}$ old. Less

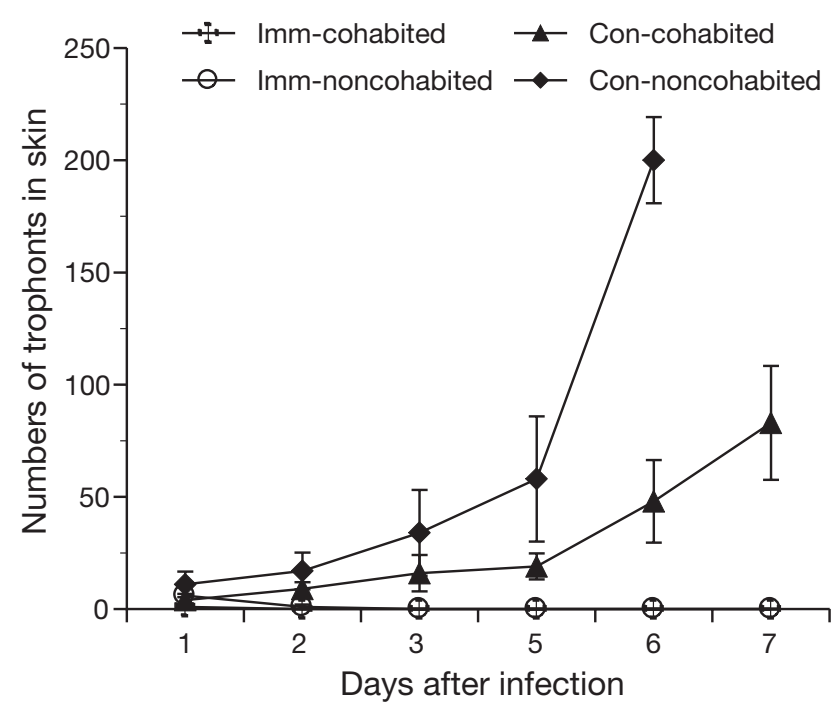

Fig. 1. Ictalurus punctatus. Number of Ichthyophthirius multifiliis trophonts in skin of fish using cohabitation challenge and challenged without cohabitation from Day 1 to 7 postexposure to 30000 theronts fish ${ }^{-1}$ for $1 \mathrm{~h}$. Parasite load was expressed as number of trophonts per skin sample (by scraping mucus and skin from a $2 \times 4 \mathrm{~cm}^{2}$ area of lateral body surface of each fish). Fish used in the cohabitation challenge included immune (Imm-cohabited) and non-immune control fish (Con-cohabited). Fish used the non-cohabitation challenges also included immune (Imm-noncohabited) and control fish (Con-noncohabited). Each value is the mean of 12 samples from 6 fish; vertical bars represent SD than $10 \%$ of the observed trophonts were mature, having a C-shaped macro-nucleus. Similar results were seen for parasite loads in gills of control fish. The numbers of trophonts in gills of cohabited control fish were lower than in non-cohabited control fish (Fig. 2). The parasite loads in gills of control fish in either cohabited or non-cohabited aquaria also increased greatly at Day 6 post-infection. From Day 6 post-infection, control fish started showing mortality in non-cohabited aquaria. Morbid catfish showed heavy loads of Ich trophonts, ranging from 20 to 50 trophonts per field of view $\left(19.6 \mathrm{~mm}^{2}\right)$ at low magnification $(40 \times)$. All control fish died in tanks without immune fish $7 \mathrm{~d}$ post-exposure to Ich theronts. One to $2 \mathrm{~d}$ post-infection, 1 out of $6 \mathrm{im}$ mune fish carried trophonts on the skin and 2 out of 3 carried trophonts on the gills. The parasite loads were light, with few trophonts per sample. Some trophonts were immobilized on skin or gills of immune fish with cilia beating. Three days post-infection, no trophonts were observed on the skin or gills of immune fish.

\section{Fish survival in challenge Trial I}

Mortalities were significantly lower $(p<0.05)$ in fish immune to Ich than non-immune controls in both cohabitation and non-cohabitation challenges

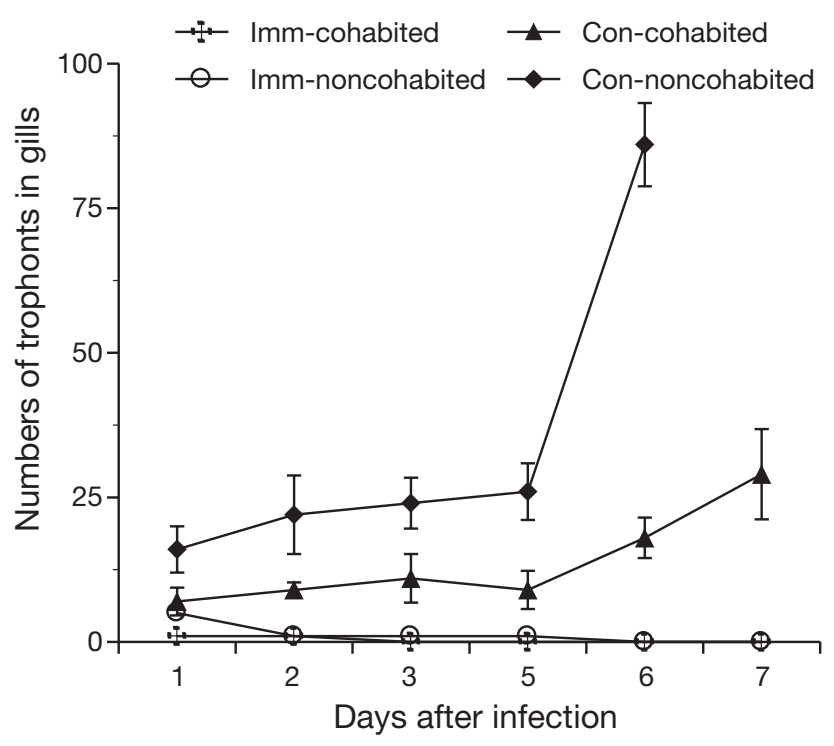

Fig. 2. Ictalurus punctatus. Number of Ichthyophthirius multifiliis trophonts in gills of fish using cohabitation challenge and non-cohabitation challenge methods from Day 1 to 7 post-exposure to 30000 theronts fish ${ }^{-1}$ for $1 \mathrm{~h}$. Fish gill filament samples $(5 \times 5 \mathrm{~mm})$ were cut from each fish and trophont loads were counted from 2 randomly selected viewing areas and expressed as number of parasite per viewing area $\left(19.6 \mathrm{~mm}^{2}\right)$. Each value is the mean of 12 samples from 6 fish; vertical bars represent SD 
Table 2. Ictalurus punctatus. Percentage of mortality, relative percent survival (RPS), and mean days to death (MDD) following exposure to Ichthyophthirius multifiliis theronts in Trial I. Forty fish were used in each group. Within a given column, means with different superscripts are statistically different $(\mathrm{p}<0.05)$. NM-immune: immunized channel catfish without calcein mark; CM-control: non-immunized control catfish marked with calcein

\begin{tabular}{|c|c|c|c|c|}
\hline Fish group & $\begin{array}{l}\text { Challenge } \\
\text { method }\end{array}$ & $\begin{array}{c}\text { Mortality } \\
(\%)\end{array}$ & $\begin{array}{l}\text { RPS } \\
(\%)\end{array}$ & $\begin{array}{l}\mathrm{MDD} \\
\pm \mathrm{SE}\end{array}$ \\
\hline NM-immune & Cohabited & $5.0 \pm 2.9^{\mathrm{a}}$ & $89.6 \pm 6.3^{\mathrm{a}}$ & $15.0 \pm 1^{a}$ \\
\hline CM-control & Cohabited & $47.5 \pm 4.8^{\mathrm{b}}$ & & $16.5 \pm 1.5^{\mathrm{a}}$ \\
\hline NM-immune & Non-cohabited & $2.5 \pm 0.5^{\mathrm{a}}$ & $96.5 \pm 3.5^{\mathrm{a}}$ & $10.0 \pm 0^{\mathrm{a}}$ \\
\hline CM-control & Non-cohabited & $67.5 \pm 2.5^{\mathrm{c}}$ & & $11.7 \pm 2.3^{\mathrm{a}}$ \\
\hline
\end{tabular}

\section{DISCUSSION}

Marking fish by calcein immersion is easily performed for large numbers of fish in a short time compared to other marking or tagging techniques (Klesius et al. 2006). Our study showed that this marking method had no effect on the susceptibility of channel catfish to Ich theronts. No difference was noted in fish infection level, mortality, and MDD caused by Ich between unmarked fish and fish marked with calcein regardless of concentration.

(Table 2). The mortalities were 47.5 and $67.5 \%$ for non-immune fish in the cohabited and non-cohabited groups, respectively. No difference was noted for RPS between fish challenged by cohabitation $(89.6 \%)$ and fish challenged without cohabitation $(96.5 \%)$. The MDD in non-immune fish was slightly longer when challenged by cohabitation (16.5 d) than in fish in the non-cohabitation challenge $(11.7 \mathrm{~d})$, but the difference was not significant $(p>0.05)$.

\section{Fish survival in challenge Trial II}

Survival of fish immune to Ich was 90 and $97.5 \%$ when exposed to theronts in the cohabitation and noncohabitation challenge, respectively (Table 3 ). These survival percentages of immune fish were significantly higher $(\mathrm{p}<0.05)$ than those of non-immune fish in both challenge methods. More than $72 \%$ of non-immune fish died in the cohabited group, and all non-immune fish died in the non-cohabitation challenge. No difference was noted for RPS between fish challenged by cohabitation and fish challenged without cohabitation ( $p>0.05)$. Most fish died between Days 10 and 15. No statistical difference was noted for MDD for nonimmune fish in these 2 challenge methods.

Table 3. Ictalurus punctatus. Percentage of mortality, relative percent survival (RPS), and mean days to death (MDD) following exposure to Ichthyophthirius multifiliis theronts in Trial II. Forty fish were used in each group. Within a given column, means with different superscripts are statistically different $(p<0.05)$. NM-immune: immunized channel catfish without calcein mark; CM-control: non-immunized control catfish marked with calcein; na: not available

\begin{tabular}{|c|c|c|c|c|}
\hline Fish group & $\begin{array}{l}\text { Challenge } \\
\text { method }\end{array}$ & $\begin{array}{c}\text { Mortality } \\
(\%)\end{array}$ & $\begin{array}{l}\text { RPS } \\
(\%)\end{array}$ & $\begin{array}{l}\mathrm{MDD} \\
\pm \mathrm{SE}\end{array}$ \\
\hline NM-immune & Cohabited & $10.0 \pm 5.8^{\mathrm{a}}$ & $86.5 \pm 9.0^{a}$ & $12.0 \pm 0^{\mathrm{a}}$ \\
\hline CM-control & Cohabited & $72.5 \pm 6.3^{\mathrm{b}}$ & & $13.3 \pm 0.4^{\mathrm{a}}$ \\
\hline NM-immune & Non-cohabited & $2.5 \pm 2.5^{\mathrm{a}}$ & $97.5 \pm 2.5^{a}$ & $13.0 \pm 0^{\mathrm{a}}$ \\
\hline CM-control & Non-cohabited & $100 \pm 0^{c}$ & & $12.2 \pm 0.1^{a}$ \\
\hline CM-control & Non-challenged & $0 \pm 0^{\mathrm{a}}$ & & na \\
\hline
\end{tabular}

The results of this study demonstrated that a cohabitation challenge could be used as an alternative challenge method in parasite studies. There was no difference in RPS of fish challenged by cohabitation and fish challenged by non-cohabitation in both trials. Cohabitation has been regarded as the challenge method that most closely mimics natural exposure (Nordmo 1997, Klesius et al. 2006). There are many factors that influence experimental results in an immunization trial, such as pathogen concentration, density of fish, water exchange, water quality, and tank volume. The cohabitation method enables treated and control fish to be compared within the same experimental unit and ensures that all test fish are exposed to the same pathogen concentration under the same trial conditions (Nordmo 1997, Klesius et al. 2006). The cohabitation challenge method uses fish as the experimental unit, which is the smallest unit that can receive a vaccine or serve as a non-vaccine control (Jarp \& Tverdal 1997, Klesius et al. 2006).

Two factors must be considered when using a cohabitation challenge: (1) antibody and other substances secreted into the water from immune fish; and (2) infection pressure that may affect immune fish survival. In a previous study, Xu \& Klesius (2003) found that fish immune to Ich secreted cutaneous antibody into the water, which had an effect on theront invasion in naïve fish cohabited with immune fish. The trophont numbers in naïve fish cohabited with immune fish were lower than naïve fish non-cohabited with immune fish. Similar results were noted in the present study when evaluating parasite loads on fish skin and gills. The numbers of trophonts on both skin and gills of control fish cohabited with immune fish were always lower than control fish maintained in aquaria without immune fish. The level of protection that immune fish provide to cohabited control fish is 
affected by the concentration of antibody and other substances secreted from immune fish in water. When antibody concentration is high enough, it may immobilize theronts (Xu et al. 2004) or induce theront apoptosis (Xu et al. 2005). If antibody to Ich is not present or present at low levels in the water, theronts will have an increased chance to infect naïve fish. Most fish challenged with Ich theronts died with MDD of $12 \mathrm{~d}$ or longer, which indicated that fish death was caused by the second or third infection cycle of Ich, since Ich completes 1 infection cycle in 5 to $6 \mathrm{~d}$ at water temperatures of 24 to $26^{\circ} \mathrm{C}$ (MacLennan 1935). It was likely that some theronts from the first cycle successfully infected naïve fish, grew to maturity, and left the host to reproduce. One tomont can easily divide into 100 to 1000 theronts in less than $24 \mathrm{~h}$ (MacLennan 1935). Water in these aquaria could have high concentrations of theronts from the second infection cycle 5 to $6 \mathrm{~d}$ postexposure to Ich and from the third infection cycle 11 to $12 \mathrm{~d}$ post exposure to Ich. A rapid increase of infective parasites may not only have killed naïve fish in groups separated from immune fish but also in groups cohabited with immune fish. Even if antibody and other substances from fish immune to Ich have an effect on theront infection, the effect could be limited if theront numbers are high in the water.

Fish infected with bacterial pathogens in cohabitation challenges produce an infection pressure (superinfection) for naïve fish held in the same tank (Nordmo 1997). Nordmo (1997) suggested that some fish die from the original inoculation challenge and others probably die from a water-borne infection due to shedding of the pathogen by the originally inoculated fish. This may also have occurred in fish challenged with Ich theronts in our study. Control fish cohabited with immune fish could be infected by Ich and develop heavy infection. After fish die, the parasite may abandon the host, reproduce into many infective theronts, and create an infection pressure for both control and immune fish. Immune fish with a strong immune response can resist theront re-infection. However, an overload of parasites could cause infection and mortality if fish lack or have a weak immune response against Ich.

In summary, marking fish by calcein immersion had no effect on the susceptibility of channel catfish to Ich theronts. The cohabitation challenge could be used as an alternative challenge method to study Ich infection, since no difference was observed in RPS of fish challenged by cohabitation and fish challenged by noncohabitation.

Acknowledgements. The authors thank Dr. K. Nusbaum, College of Veterinary Medicine, Auburn University, and Dr. T. Welker, USDA, ARS Aquatic Animal Health Research
Laboratory, for critically viewing the manuscript. We also thank J. Mladek and C. Day for their excellent help in the laboratory and experimental fish facilities. Mention of trade or manufacturer names is solely for providing specific information and does not imply endorsement by the U.S. Department of Agriculture.

\section{LITERATURE CITED}

Areerat S (1974) The immune response of channel catfish, Ictalurus punctatus (Rafinesque), to Ichthyophthirius multifiliis. Master's thesis, Auburn University, Auburn, AL

Buchmann K, Uldal A, Lyholt HCK (1995) Parasite infections in Danish trout farms. Acta Vet Scand 36:283-298

Burkart MA, Clark TG, Dickerson HW (1990) Immunization of channel catfish, Ictalurus punctatus Rafinesque, against Ichthyophthirius multifiliis (Fouquet): killed versus live vaccines. J Fish Biol 13:401-410

Clark TG, Lin TL, Dickerson HW (1996) Surface antigen cross-linking triggers forced exit of a protozoan parasite from its host. Proc Natl Acad Sci USA 93:6825-6829

Dalgaard M, Buchmann K, Li A (2002) Immunization of rainbow trout fry with Ichthyophthirius multifiliis sonicate: protection of host and immunological changes. Bull Eur Assoc Fish Pathol 22:287-297

Dickerson H, Clark T (1998) Ichthyophthirius multifiliis: a model of cutaneous infection and immunity in fishes. Immunol Rev 166:377-384

Dickerson HW, Dawe DL, Gratzek JB, Pyle SW (1981) Induction of Ichthyophthirius multifiliis Fouquet infections in channel catfish, Ictalurus punctatus Rafinesque: standardization of the procedure. Dev Biol Stand 49:331-336

Erdal JI, Reitan LJ (1992) Immune response and protective immunity after vaccination of Atlantic salmon (Salmo salar L.) against furunculosis. Fish Shellfish Immunol 2: 99-108

Goven BA, Dawe DL, Gratzek JB (1980) Protection of channel catfish, Ictalurus punctatus Rafinesque, against Ichthyophthirius multifiliis Fouquet by immunization. J Fish Biol 17:311-316

He J, Yin Z, Xu G, Gong Z, Lam TJ, Sin YM (1997) Protection of goldfish against Ichthyophthirius multifiliis by immunization with a recombinant vaccine. Aquaculture 158:1-10

Hines RS, Spira DT (1974) Ichthyophthiriasis in the mirror carp Cyprinus carpio (L.) V. Acquired immunity. J Fish Biol 6: 373-378

Houghton G, Matthews RA (1990) Immunosuppression in juvenile carp, Cyprinus carpio L.: the effects of the corticosteroids triamcinolone acetonide and hydrocortisone 21-hemisuccinate (cortisol) on acquired immunity and the humoral antibody response to Ichthyophthirius multifiliis Fouquet. J Fish Dis 13:269-280

Jarp J, Tverdal A (1997) Statistical aspects of fish vaccination trials. In: Gudding R, Lillehaug A, Midtlyng PJ, Brown F (eds) Fish vaccinology, Vol 90. Karger Publishers, Basel, p 311-320

Klesius PH, Evans JJ, Shoemaker CA, Pasnik DJ (2006) A vaccination and challenge model using calcein marked fish. Fish Shellfish Immunol 20:20-28

Lin TL, Clark TG, Dickerson H (1996) Passive immunization of channel catfish (Ictalurus punctatus) against the ciliated protozoan parasite Ichthyophthirius multifiliis by use of murine monoclonal antibodies. Infect Immun 64:4085-4091

MacLennan RF (1935) Observations on the life cycle of Ichthyophthirius, a ciliate parasitic on fish. Northwest Sci 9: 12-14 
Nigrelli RF, Pokorny KS, Ruggieri GD (1976) Notes on Ichthyophthirius multifiliis, a ciliate parasitic on freshwater fishes, with some remarks on possible physiological races and species. Trans Am Microsc Soc 95:607-613

Nordmo R (1997) Strengths and weaknesses of different challenge methods. In: Gudding R, Lillehaug A, Midtlyng PJ, Brown F (eds) Fish vaccinology, Vol 90. Karger Publishers, Basel, p 303-309

Paperna I (1972) Infection by Ichthyophthirius multifiliis of fish in Uganda. Prog Fish Cult 34:162-164

Raynard RS, Snow M, Bruno DW (2001) Experimental infection models and susceptibility of Atlantic salmon Salmo salar to a Scottish isolate of infectious salmon anemia virus. Dis Aquat Org 47:169-174

SAS Institute (1989) SAS/Stat user's guide, Ver 6, 4th edn. SAS Institute, Cary, NC

Sigh J, Buchmann K (2001) Comparison of immobilization assays and enzyme linked immunosorbent assays for detection of rainbow trout antibody-titres against Ichthyophthirius multifiliis Fouquet. J Fish Dis 24:49-51

Tieman M, Goodwin AE (2001) Treatments for Ich infections in channel catfish evaluated under static and flow-through water conditions. N Am J Aquac 63:293-299

Traxler GS, Richard J, McDonald TE (1998) Ichthyophthirius multifiliis (Ich) epizootics in spawning sockeye salmon in British Columbia, Canada. J Aquat Anim Health 10:143-151

Editorial responsibility: Dieter Steinhagen,

Hannover, Germany
Wahli T, Meier W (1985) Ichthyophthiriasis in trout: investigation of natural defense mechanisms. In: Ellis AE (ed) Fish and shellfish pathology. Academic Press, London, p 347-352

Wang X, Dickerson HW (2002) Surface immobilization antigen of the parasitic ciliate Ichthyophthirius multifiliis elicits protective immunity in channel catfish (Ictalurus punctatus). Clin Diagn Lab Immunol 9:176-181

Wolf K, Markiw MA (1982) Ichthyophthiriasis: immersion immunization of rainbow trout (Salmo gairdneri) using Tetrahymena thermophila as a protective immunogen. Can J Fish Aquat Sci 39:1722-1725

$\mathrm{Xu}$ DH, Klesius PH (2003) Protective effect of cutaneous antibody produced by channel catfish, Ictalurus punctatus (Rafinesque), immune to Ichthyophthirius multifiliis Fouquet on cohabited non-immune catfish. J Fish Dis 26: 287-291

Xu DH, Klesius PH, Shelby RA (2004) Immune responses and host protection of channel catfish, Ictalurus punctatus (Rafinesque), against Ichthyophthirius multifiliis after immunization with live theronts and sonicated trophonts. J Fish Dis 27:135-141

Xu DH, Klesius PH, Shoemaker CA (2005) Cutaneous antibodies from channel catfish, Ictalurus punctatus (Rafinesque), immune to Ichthyophthirius multifiliis (Ich) may induce apoptosis of Ich theronts. J Fish Dis 28:213-220

Submitted: October 4, 2006; Accepted: December 1, 2006

Proofs received from author(s): February 6, 2007 